\title{
CARBON DIOXIDE IN CAVE ATMOSPHERES. NEW RESULTS IN BELGIUM AND COMPARISON WITH SOME OTHER COUNTRIES
}

\author{
CAMILLE EK* \\ Laboratoire de Géomorphologie et de Géologie du Quaternaire, Université de Liège, Place du 20-Août, 7, B-4000 Liège, Belgium \\ AND \\ MICHEL GEWELT $\dagger$ \\ Centre d'Etude de l'Energie Nucléaire (CEN/SCK), Mesures Bas-Niveaux, Boeretang, 200, B-2400 Mol, Belgium
}

Received 15 December 1983

Revised 24 May 1984

\begin{abstract}
More than 600 measurements of the carbon dioxide content of cave air in Belgium lead up to the conclusion that the main More than 600 measurements of the carbon dioxide content of distribution are: (1) a flow originating from the biomass and diffusing in the soil and the voids of bedrock; (2) a trend, discernible in very still air only, to go down by density; (3) in some caves, draughts caused, for instance, by a swift underground stream.

Results in Belgium are compared with published and unpublished data from other countries, showing that $\mathrm{CO}_{2}$ is often less abundant in cold climate caves and in caves of semi-arid regions (influence of the biomass).

Special attention is paid to human contamination during analyses: the influence of people passing through the cave nearby the operator, but also the influence of the operator himself are discussed, and the use of special precautions (including a $\mathrm{CO}_{2}$-absorbing mask) in defined critical situations is stressed.
\end{abstract}

KEY WORDS Carbon dioxide Caves Human contamination Seasonal variations

\section{INTRODUCTION}

Carbon dioxide is of paramount importance in limestone solution. Although the action of other acids is neither ignored nor underestimated here, it is obvious, at least in temperate and cold regions, that carbonic gas is in most cases the prime mover and the main agent of carbonate dissolution.

Carbon dioxide in water comes either directly from the air or from the metabolism of the biomass - and in this case also, often through a gaseous phase-hence the primordial interest of knowing the $\mathrm{CO}_{2}$ concentrations and movements in the limestone environments, particularly in cave air, in soil air and in the lowermost atmosphere.

More than 600 measurements of carbon dioxide have been carried out in Belgium, all of them carefully located in space, time and weather conditions. We try here to summarize in a few pages the main results of these analyses and to compare them with some other studies of carbonic gas all over the world.

- Chef de travaux.

† Research Assistant. National Fund for Scientific Research (F.N.R.S., Belgium).

$0197-9337 / 85 / 020173-15 \$ 01.50$

(C) 1985 by John Wiley \&.Sons, Ltd. 


\section{METHODS AND TECHNIQUES}

\section{Methods of measurement}

All our recent measurements are done with a gas pump detector (Bendix-Gastec). The Gastec detector tubes $\left(2 \mathrm{LL}\right.$ or $2 \mathrm{~L}$ ) give a direct reading of the $\mathrm{CO}_{2}$ concentration in the air $(\mathrm{ppm} / \mathrm{vol}) .{ }^{*}$ Before, an electrolytic field device had been used (Koepf, 1952; Hilger, 1963; Delecour, 1965; Ek et al., 1968; Delecour et al., 1968). This system, based on the electrolysis of a $\mathrm{NaCl}$ solution which had absorbed $\mathrm{CO}_{2}$, is more precise $( \pm 0.1 \mathrm{mg}$ $\mathrm{CO}_{2} / 1$ i.e. $60 \mathrm{ppm}: \mathrm{Ek}, 1981$ ) but heavier and slower. Thus, for field investigation, the Gastec pump system is more useful: it is very light and only 2 or 3 minutes are needed for one measurement. The minimal precision, guaranteed by the manufacturer, is \pm 25 per cent but it seems that the effective precision is better and the reproducibility of measurements is \pm 10 per cent (Ek et al., 1981). When we express the results in ppm/vol, we refer to the Gastec detector measurements. For older measurements done with the electrolytic method, we keep the expression of the results in $\mathrm{mg} \mathrm{CO}_{2} / 1$. The equivalence depending among other things on temperature is about $0.18 \mathrm{mg} / 1=100 \mathrm{ppm} / \mathrm{vol}$ in TPN conditions.

\section{Precaution during the measurements}

With respect to the human breathing out $\mathrm{CO}_{2}$ (about $40 \cdot 10^{3} \mathrm{ppm}$ : Miotke 1974), it is very important to avoid human exhalation during the measurements. A carbon dioxide absorber system has been systematically used when measurements have been carried out in fissures, joints, and confined atmosphere. This system, described in Figure 1, is composed of a plexiglas surrounding wall in the form of a $Y$ branch, with two valves of large diameter $(\sim 2.5 \mathrm{~cm})$. The inlet valve opens to the cave air, and the air breathed in and out is ejected through the outlet valve into a stainless steel reservoir filled with soda lime. The exhaled $\mathrm{CO}_{2}$ is then absorbed by this soda lime. A rubber mouth piece-coming from a snorkel-is fixed to the plexiglas surrounding wall and a nose clip obliges the operator to breathe by the mouth. The rubber mouth piece combined with the nose clip is more comfortable than the 'total' nose and mouth mask we used before. The necessity of using this $\mathrm{CO}_{2}$ absorber system is evident and will be demonstrated later. In the same way, we do not use acetylene (carbide lamp), but only electric light during analyses.

\section{RESULTS AND DISCUSSION FOR BELGIAN CAVES}

\section{Fissures versus larger passages}

Cave air generally contains more carbon dioxide than the open atmosphere. Under temperate conditions, the $\mathrm{CO}_{2}$ pressure in the caves is generally two to twenty times higher than in open air, sometimes more. In the caves, the first differentiation to appear to the air-analyst is grossly related to the width of the cavity: the fissures generally display a higher $\mathrm{CO}_{2}$ content than larger passages, namely galleries and chambers. In the Trou Joney, at Comblain, a very shallow cave, values of 7.8 and $10.6 \mathrm{mg} \mathrm{CO}_{2} / 1$ air (approximately 4300 and $5900 \mathrm{ppm}$ ) measured in fissures in July 1966 were 3 or 4 times higher than the values displayed by the passageways (Ek et al., 1968). Similar observations were carried out in Poland (Ek et al., 1969). In Brialmont Cave and in Ste-Anne Cave, both at Tilff, fissures have a higher $\mathrm{CO}_{2}$ content than the respective passages of these caves (see Figure 3). In Rochefort Cave, the $\mathrm{pCO}_{2}$ is diminishing from the fissures to the bulk of the atmosphere of a large chamber, The Hell, both in May and September (Figure 2). The strong gradient of $\mathrm{pCO}_{2}$ at the outlet of the fissure seems to indicate that the carbon dioxide diffuses from the crack into the chamber (Delecour et al., 1968; Ek, 1969).

Some fissures do not display a high $\mathrm{pCO}_{2}$. But, although not universal, the distinction between fissures and

*To convert the $\mathrm{CO}_{2}$ concentration (in ppm by volume) into partial pressure ( $\mathrm{PCO}_{2}$ in atmosphere), the following expression can be used:

where: $P$ atmos. $=$ barometric pressure (in $\mathrm{mm} \mathrm{Hg}$ )

$$
\mathrm{pCO}_{2} \text { (in atm.) }=\frac{\mathrm{ppm} \mathrm{CO}_{2} \times(P \text { atmos. }-P w)}{76010^{6}}
$$

$P_{w} \quad=$ water vapor pressure (in $\mathrm{mm} \mathrm{Hg}$ )

$\left(9 \mathrm{~mm} \mathrm{Hg}\right.$ at $\left.10^{\circ} \mathrm{C}\right)$ 


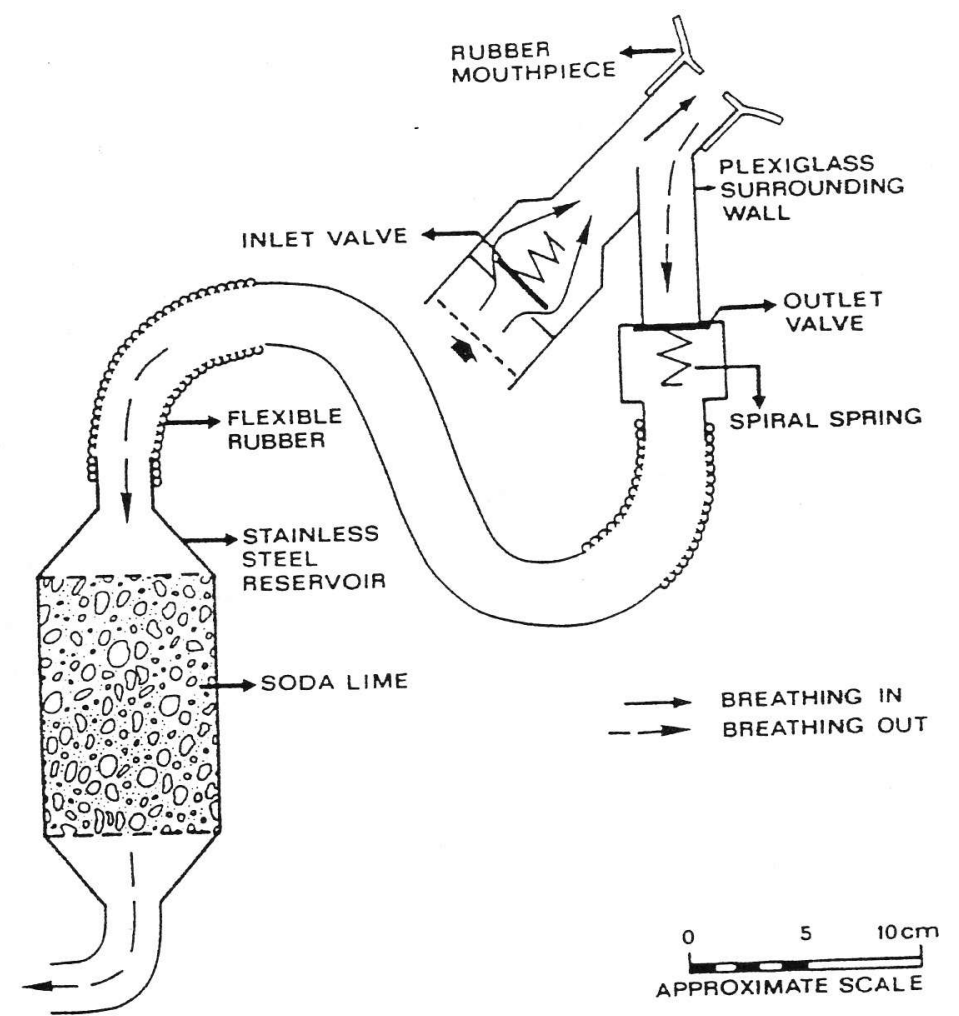

Figure 1. $\mathrm{CO}_{2}$-absorbing device used in confined sites. The air breathed out by the operator passes through soda lime before being returned to the cave atmosphere

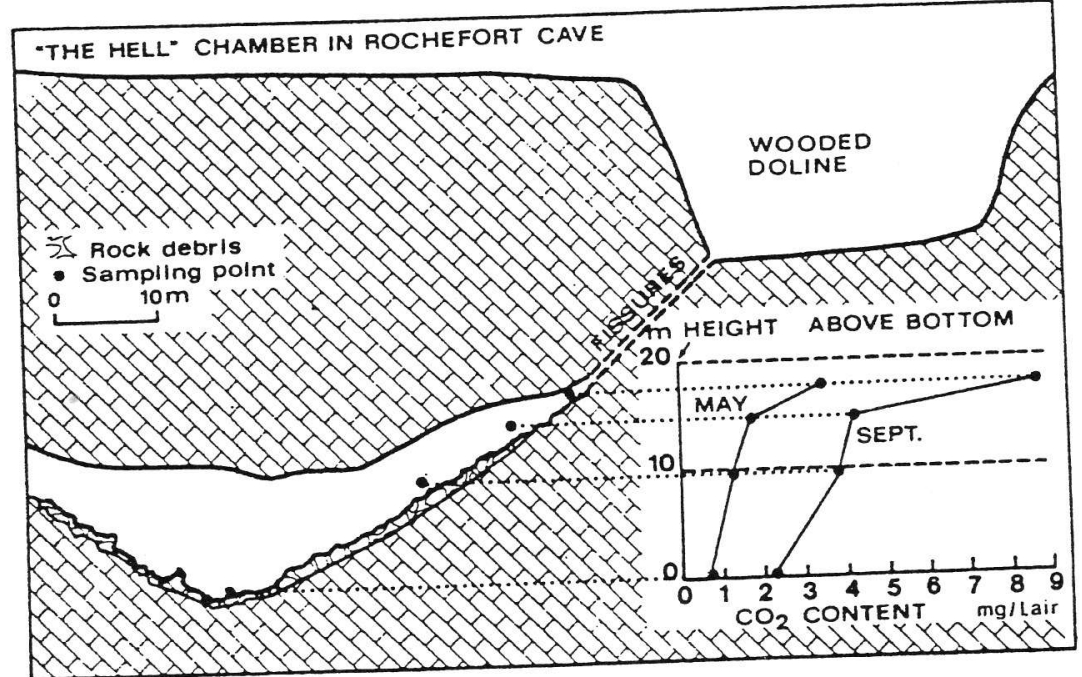

in the air of 'The Hell', a large chamber in Rochefort Cave. Cross-section showing sampling locations and $\mathrm{CO}_{2}$ Figure 2. $\mathrm{CO}_{2}$ titrations in the air of 'The Hell', a large chamber in Rochefort Cave. Cross-section showing al, 1968)

larger passages is very general, particularly in shallow or not too deep caves. In Belgium, most accessible fissures are in the upper part of the galleries and passages, and thus, as for fluids, there is likely to be a possible connection between the soil and the cave. This probably explains, for instance, that the gradient of $\mathrm{CO}_{2}$ 
between the cracks and the main passages is steeper in Brialmont Cave (a very shallow cave) than in Ste-Anne,
which is deeper lying.

\section{Flow of carbon dioxide from the surface soil}

As shown in Figure 2, the maximum $\mathrm{pCO}_{2}$ is observed, in the cave considered, in a fissure connected with the ground below a wooded doline. This fact, and the downward gradient shown on this figure from the

The observation

originates. This is corroborated by water analyes (Ek allowed the calculation of $\mathrm{pCO}_{2}$ of an atmosphere in 1969$)$ : the titrations of 32 underground seepage waters times higher than normal $\mathrm{pCO}_{2}$ in open . This is, in Belgium, generally not true of underground rivers, but it

A similar conclusion is reached by Delhez (1972) ceiling, and thus coming from the soil.

abundance in caves. Yet in 1937, Adams and (1972) about the importance of biogenic processes on $\mathrm{CO}_{2}$ 90 times the amount of $\mathrm{CO}_{2}$ normally found innerton have shown that the $\mathrm{CO}_{2}$ content in the soil is 25 to

found in the atmosphere.

environments. A lot of parameters (measurements have been done in the soil atmosphere, in varied edaphic involved in the $\mathrm{CO}_{2}$ production in soils. (1977); Bakalowicz (1979); Bögli (1969, 1976); references on that matter can be found for example in: Atkinson et al. (1983); Jakucs (1977); Miotke (1974); Dever et al. (1983); Dumont et al. (1983); Galimov (1966); Haas and Russel (1950).

\section{Seasonal evolution}

The biogenic origin of most $\mathrm{CO}_{2}$ induces a seasonal variation of its pressure. This was shown by Ek (1979) but was already suggested in Ek et al. (1968). The first clear and statistically significant confirmation of this
fact was given by Gewelt and Ek (1985).

Figure 3 shows the differences between the $\mathrm{pCO}_{2}$ figures of January and September obtained in two fissures, in a wet passage. January and September correspond respectively to the minimum and maximum values in than one half of the September values.

Some 237 measuremen

the results are summarized in Figures 4 and 5 . ying a few metres maximum extending through the whrface, the $\mathrm{CO}_{2}$ content of the air begins to increase in June and displays a metres below the surface of the plateau, summer, whereas in Ste-Anne Cave, lying some eighty to one hundred maximum at the end of September.

In the fissures, the fact that the flow maximum pressure of $\mathrm{CO}_{2}$ is earlier in $\mathrm{CO}_{2}$ is coming from the soil is obvious if one considers that the maximum is displayed earlier in the fissures of the upper level beneath in Ste-Anne Cave, but moreover the F3 and F4 of the lower level of fissures of the upper level of Brialmont Cave, F1 and F2, than in the cracks

The diffusion of $\mathrm{CO}_{2}$ is schematically cave (see Figure 5).

\section{Vertical differentiation}

In a single room or gallery the $\mathrm{pCO}_{2}$ is frequently higher near the roof than near the ground. In this case, there is no static density equilibrium $\left(\mathrm{CO}_{2}\right.$ is denser than air) and the gradient is an inverse density gradient. This kind of vertical distribution as shown by Ek et al. $(1968,1969)$ may be related either with temperature, which explains the high $\mathrm{pCO}_{2}$ observed near the ceiline soil is perhaps warmer and above all richer in $\mathrm{CO}_{2}$ fractured upper zone is clearly shown in Figure 2 .
However, it is also frequent Thenomenon of soil $\mathrm{CO}_{2}$ coming from the

However, it is also frequent to ohserve a normal density gradient: $\mathrm{CO}_{2}$ contents are higher near the bottom. 


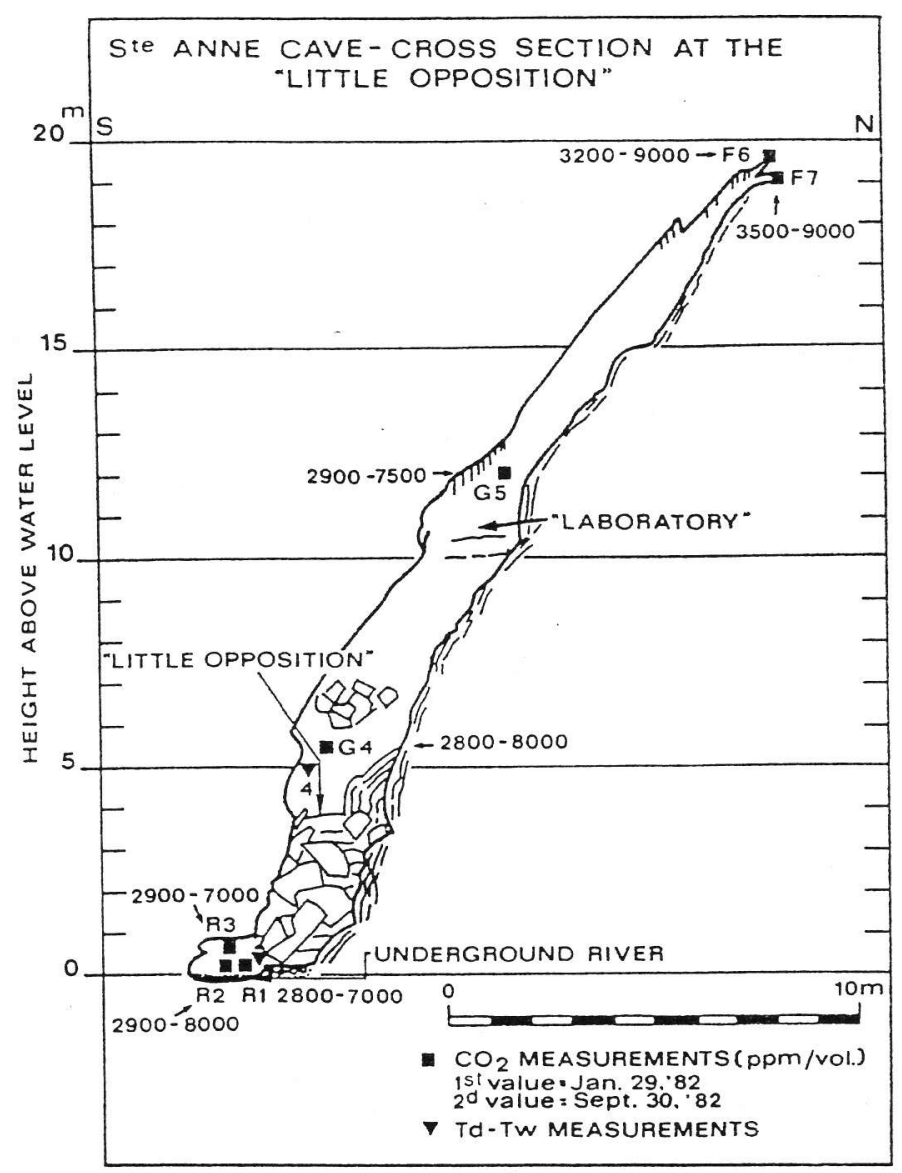

Figure 3. $\mathrm{CO}_{2}$ titrations in Ste-Anne Cave. Cross-section of the main passage, $340 \mathrm{~m}$ east of the entrance, showing sampling locations and observed values in January and September. Squares refer to $\mathrm{CO}_{2}$ measurements, triangles to temperature and moisture measurements. The cross-section is somewhat schematized, all points being not really in a vertical plane (after Gewelt and Ek. 1985)

For example in the Comblain-au-Pont cave (Figure 7), the $\mathrm{pCO}_{2}$ increases from the entrance to the bottom. Nearby the entrance of the cave, the $\mathrm{CO}_{2}$ content corresponds to the normal open air value $(330 \mathrm{ppm})$, afterwards the $\mathrm{pCO}_{2}$ increases to the bottom. An inversion was found in the little chamber situated $3.5 \mathrm{~m}$ over the bottom: the higher $\mathrm{CO}_{2}$ content in this zone may be due to the diffusion or also to the confined morphology of the little chamber (Delecour et al., 1968; Ek et al., 1968).

The general downwards increasing $\mathrm{CO}_{2}$ gradient can be due to an accumulation by gravity. This phenomenon can also be reinforced by a thermal inversion which catches the air near the bottom. Referring to the Figure 8 where the temperature variations (in ${ }^{\circ} \mathrm{C}$ ) and relative humidity (percentage) are shown during one year in Ste-Anne and Brialmont caves, it can be seen that there is a thermal inversion in the main passage of Brialmont cave the whole year long. The cold air is always caught near the bottom of the gallery (G6) and the warmer air is located near the roof (G7). This thermal inversion is more important during the summer (difference of $2.5^{\circ} \mathrm{C}$ ) and is accompanied by a $\mathrm{CO}_{2}$ stratification which can be seen in Figure $4(\mathrm{G} 6-\mathrm{G} 7$ ) and Figure 5 (F1-F2, F3-F4) (Gewelt and Ek, 1985). The thermal inversion blocks the $\mathrm{CO}_{2}$ and the colder air in the lower passage. A measurement done at mid-height (September 30, 1982), between $G 6$ and $G 7$ shows that the richer $\mathrm{CO}_{2}$ layer is not only located near the bottom but also in the half of the height of the gallery. Thus the downwards $\mathrm{CO}_{2}$ increasing gradient is related with a gravity stratification, accentuated by a thermic inversion. This may be a normal situation in caves where air circulation (and ventilation) are reduced and where stratification is possible. Vertical caves are probably a better trap for $\mathrm{CO}_{2}$. 
SEASONAL $\mathrm{CO}_{2}$ VARIATIONS IN GALLERIES

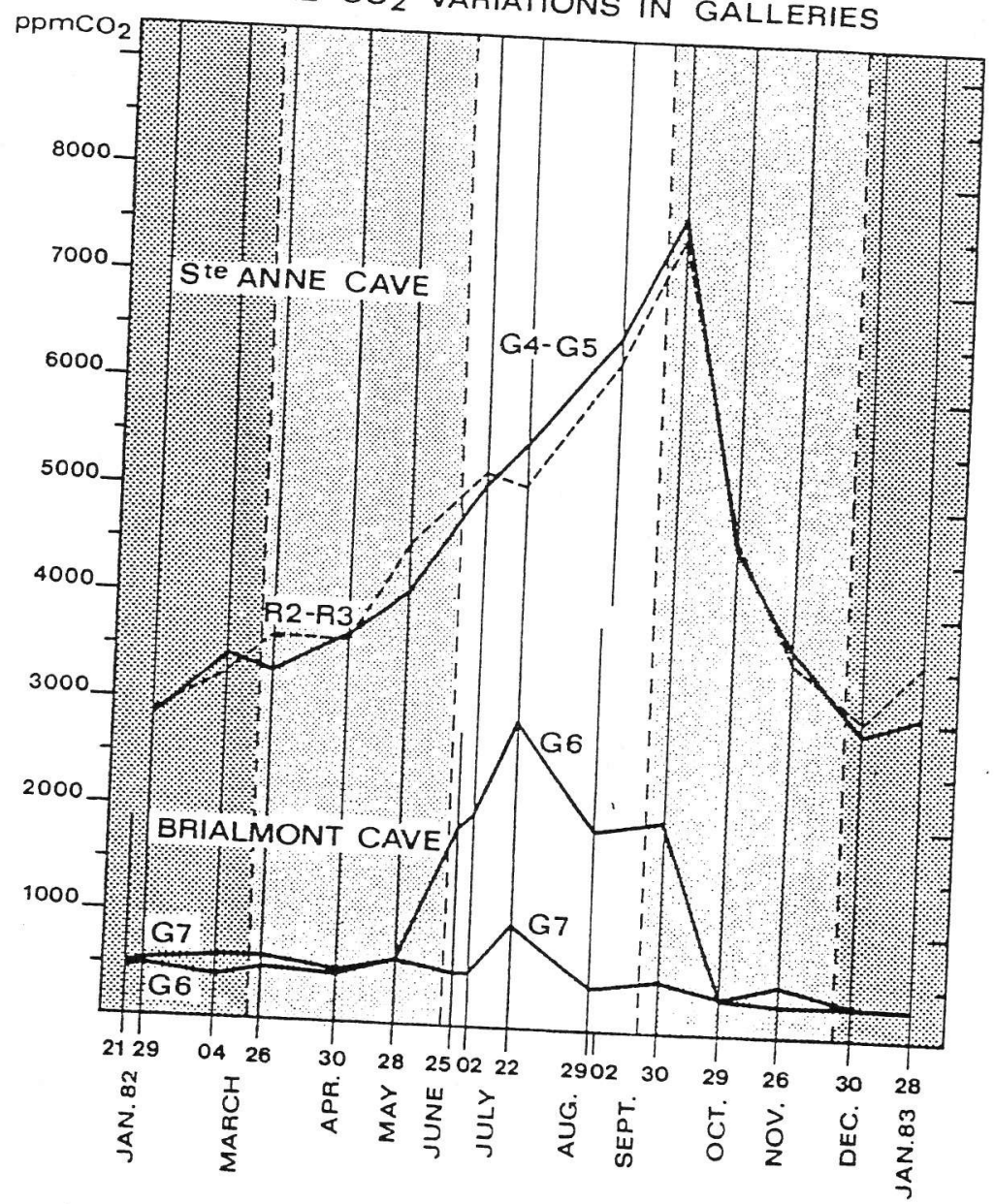

Figure 4. Seasonal evolution of the $\mathrm{CO}_{2}$ content of the

underground river; G: dry passageway (modified from Gewelt and Ek 1985) Caves. R: wet passage: the

In Figure 8 it can also be seen that the relative humidity in Ste-Anne cave is very high and constant (98 to
00 per cent). This short range may be correlated whe with the presence of an underground river. Dripping the confined zone where measurements were done and atmosphere. In Brialmont cave, the relativ. Dripping water contributes also to the saturation of the cave cent), as a consequence of the two opposite entrances always high but more variable (from 91 to 100 per

\section{Horizontal gradient}

An horizontal gradient of $\mathrm{CO}_{2}$ is frequently observed in horizontal caves. This was shown for the first time more abundant towards the end of the the winter. The $\mathrm{CO}_{2}$ gas in the cave atmosphere becomes more and

The same phenomenon, but above the Rubi, because the distal zones are more confined.

contents of air $20 \mathrm{~cm}$ above water level decreases from the Remouchamps cave, is shown in Figure $9 . \mathrm{CO}_{2}$ with high $\mathrm{CO}_{2}$ values and when the river emerges frem sump to the exurgence. The water is in equilibrium cave, $\mathrm{CO}_{2}$ comes out the water to the air (the diffusion rate is ump and enters in the accessible passage of the lower downstream and the cave ventilation is improved, whis very high). The $\mathrm{CO}_{2}$ excess of the water becomes (Delecour et al., 1968; Ek et al., 1968). An example combining the two 


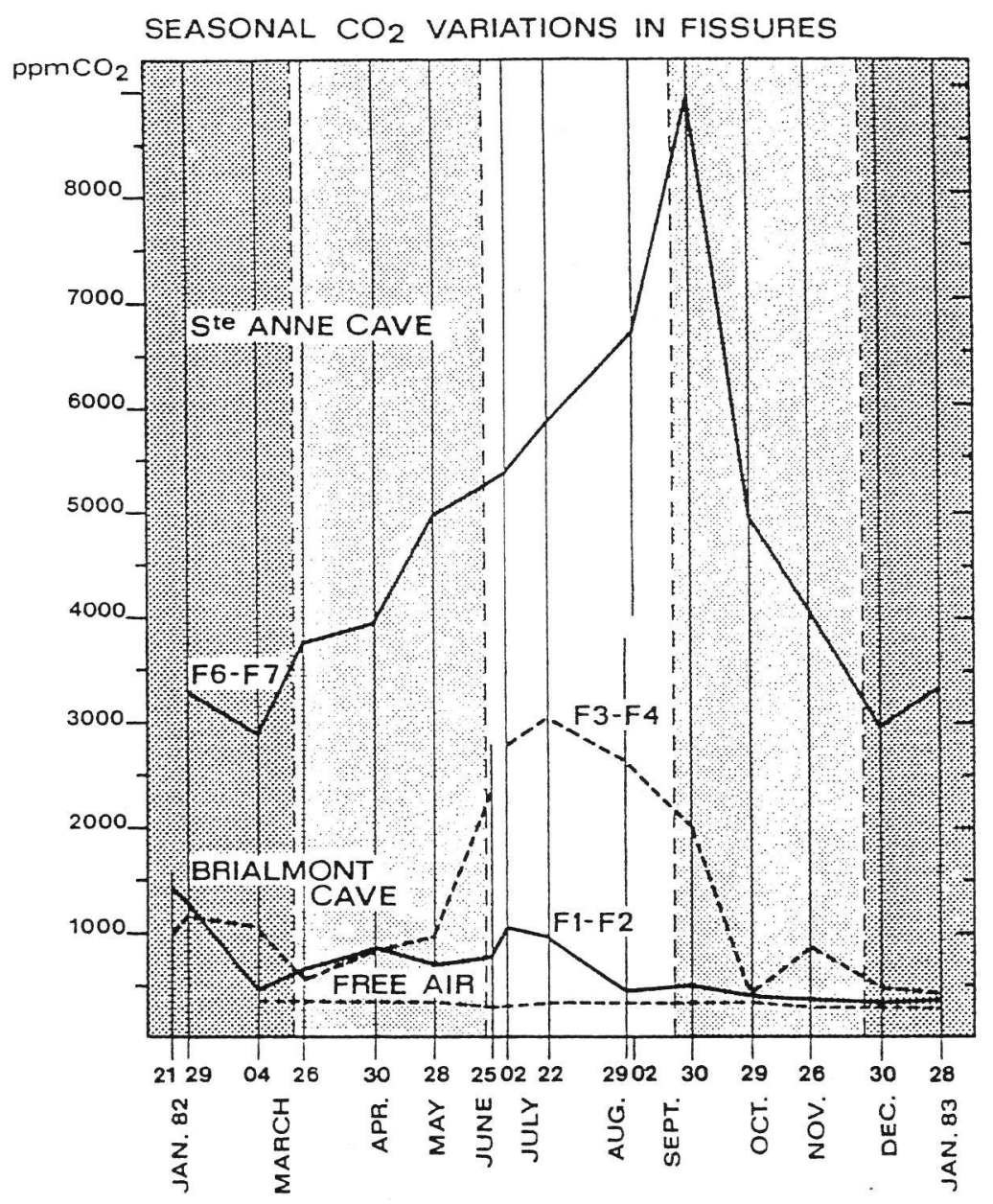

Figure 5. Seasonal evolution of the $\mathrm{CO}_{2}$ content of the fissures of Ste-Anne and Brialmont Caves. Each line is the mean of the measured values in two adjacent fissures (modified from Gewelt and Ek, 1985)

air) has been found in Ste-Anne cave by Gewelt and Ek (1985). Referring to Figure 10 where 27 measurements carried out on January 7, 1983 along the main passage of Ste-Anne cave are reported, an increase of $\mathrm{CO}_{2}$ concentration in cave atmosphere from the entrance to the end of the cave can be observed. Linear regression 3 is calculated with all the measures. The correlation coefficient, $r=0.96$ is very high and gives evidence of the existence of a positive linear relation between $\mathrm{CO}_{2}$ content and distance from the entrance. This phenomenon can first be correlated with the decrease of the ventilation towards the end of the cave. However, it can be seen in Figure 10 that two measurement clusters are distinguishable and that they are separated by a threshold of about $800-1000 \mathrm{ppm}$. This first group of measurements is located near the entrance and corresponds to the dry part of the cave. The $\mathrm{pCO}_{2}$ increases from 300 (free air) to $1500 \mathrm{ppm}$ at $160 \mathrm{~m}$ from the entrance. The correlation coefficient (linear regression 1) is $r=0.83$. For the second group of measurements (linear regression 2), $r=0.89$ and the $\mathrm{CO}_{2}$ concentrations are higher towards the sump (end of the cave). It is very interesting to see that the threshold between the two groups of measurements corresponds to the vanishing of the underground river into the lower passage of the cave. The $\mathrm{CO}_{2}$ content is maximum ( $3200 \mathrm{ppm}$ ) upstream then decreases downstream and, when the underground river disappears in the lower gallery, the $\mathrm{CO}_{2}$ concentration falls down about $800-1000 \mathrm{ppm}$ and then continues to decrease up to the entrance.

One might assume that the progressive lowering of $\mathrm{CO}_{2}$ content of the air downstream shows variations of equilibrium between air and water. There is no doubt that the underground river is a purveyor of $\mathrm{CO}_{2}$ for the 


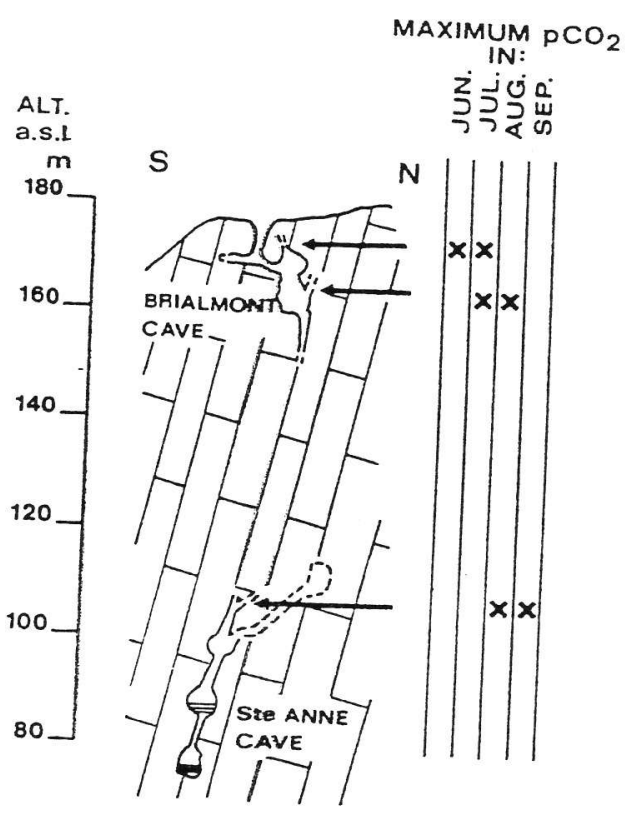
Figure 6. Schematic cross-section of Ste-Anne and Brialmont Caves, at Tilff. Seasonal diffusion of carbon dioxide, as revealed by the
measurements summarized in Figures 4 and 5

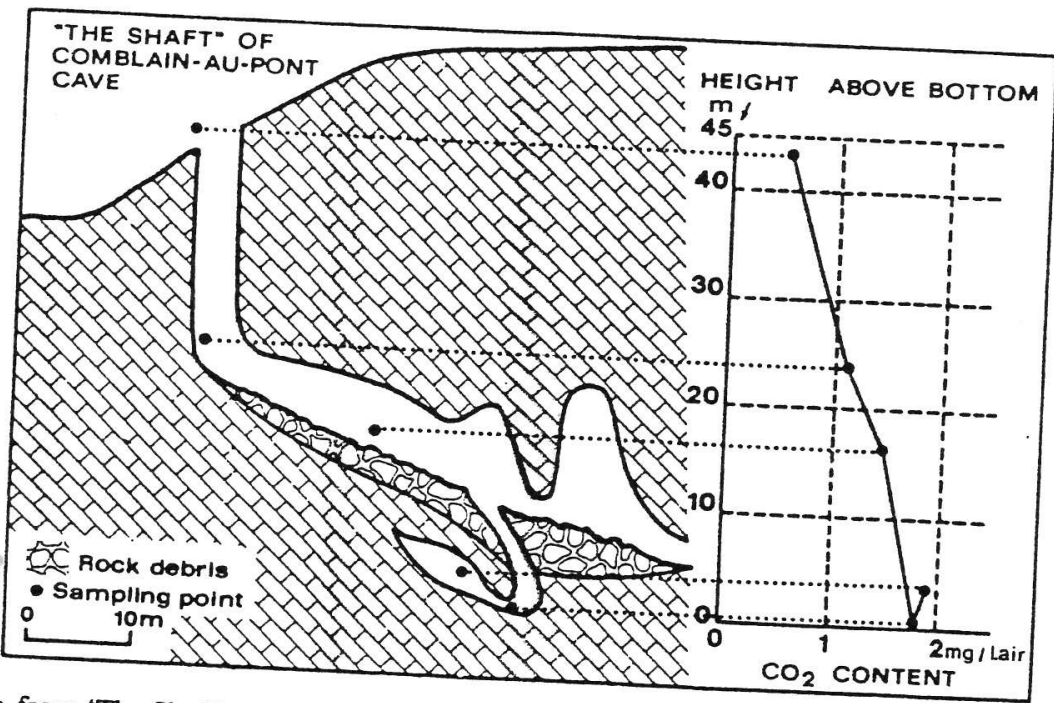

Figure 7. Cross-section from 'The Shaft' of Comblain entrance to bottom (after Delecour et al., 1968)

cave air, in any case when $\mathrm{pCO}_{2}$ of water is higher than $\mathrm{pCO}_{2}$ of atmosphere. This $\mathrm{CO}_{2}$ supply from the water just above the water than $160 \mathrm{~cm}$ above (see ${ }^{2}$ done $10 \mathrm{~cm}$ above the water level: $\mathrm{pCO}_{2}$ is generally higher

\section{Contaminations}

has been identified. For more details about this of Figures 4 and 5 are too high because $\mathrm{CO}_{2}$ contamination has identified. For more details about this feature, we refer to our previous paper (Gewelt and $\mathrm{Ek}, 1985$ ). 

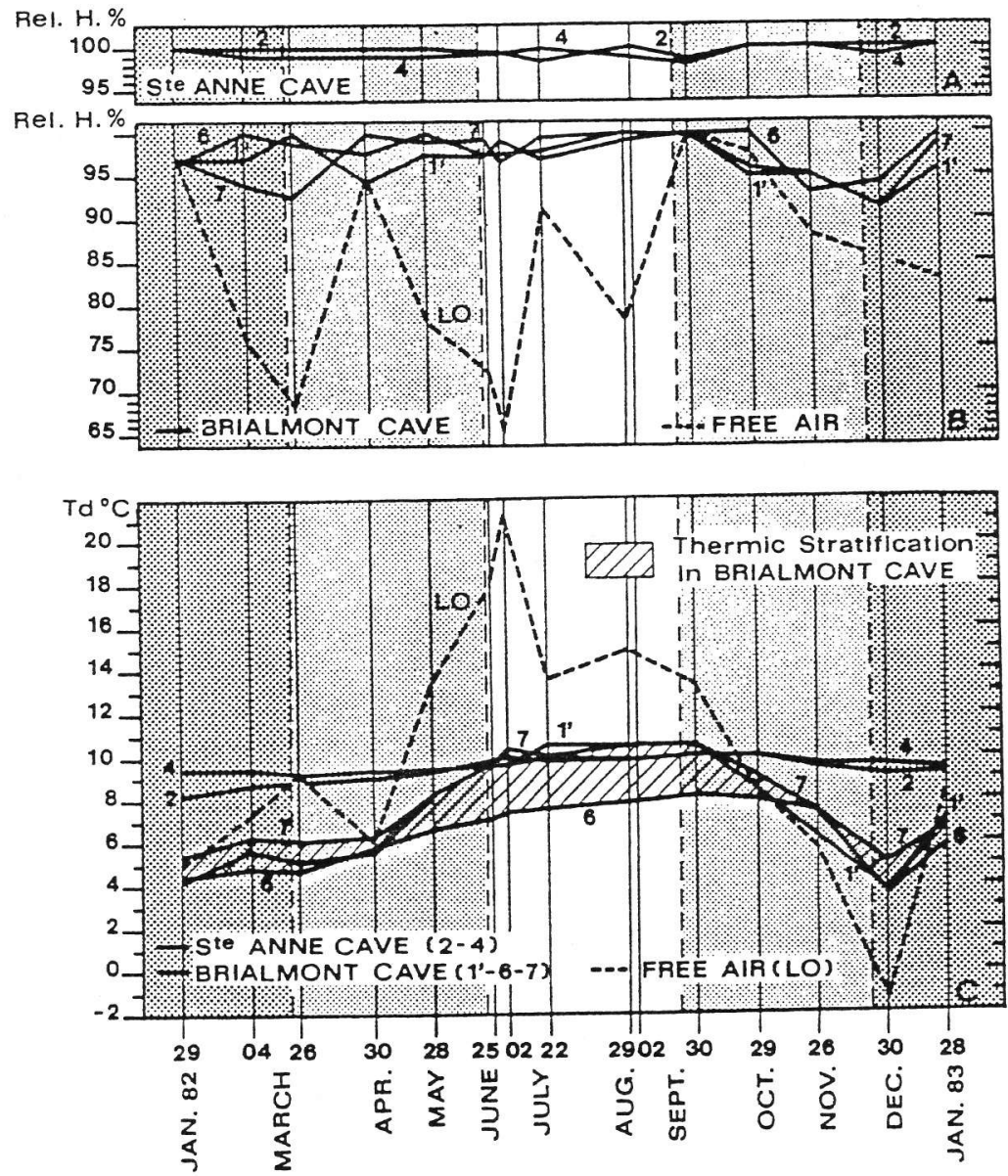

Figure 8. Seasonal evolution of the relative humidity and temperature in Ste-Anne and Brialmont caves. The hachured zone shows the thermal inversion in Brialmont cave (after Geweit and Ek, 1985)

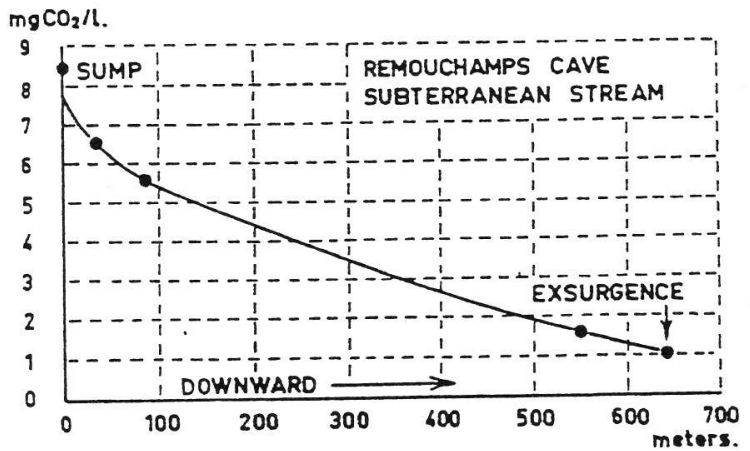

Figure 9. Evolution of $\mathrm{CO}_{2}$ content of air $20 \mathrm{~cm}$ above water level between the sump and the exurgence in the Remouchamps cave. The distance is measured along the stream (after Delecour et al., 1968) 


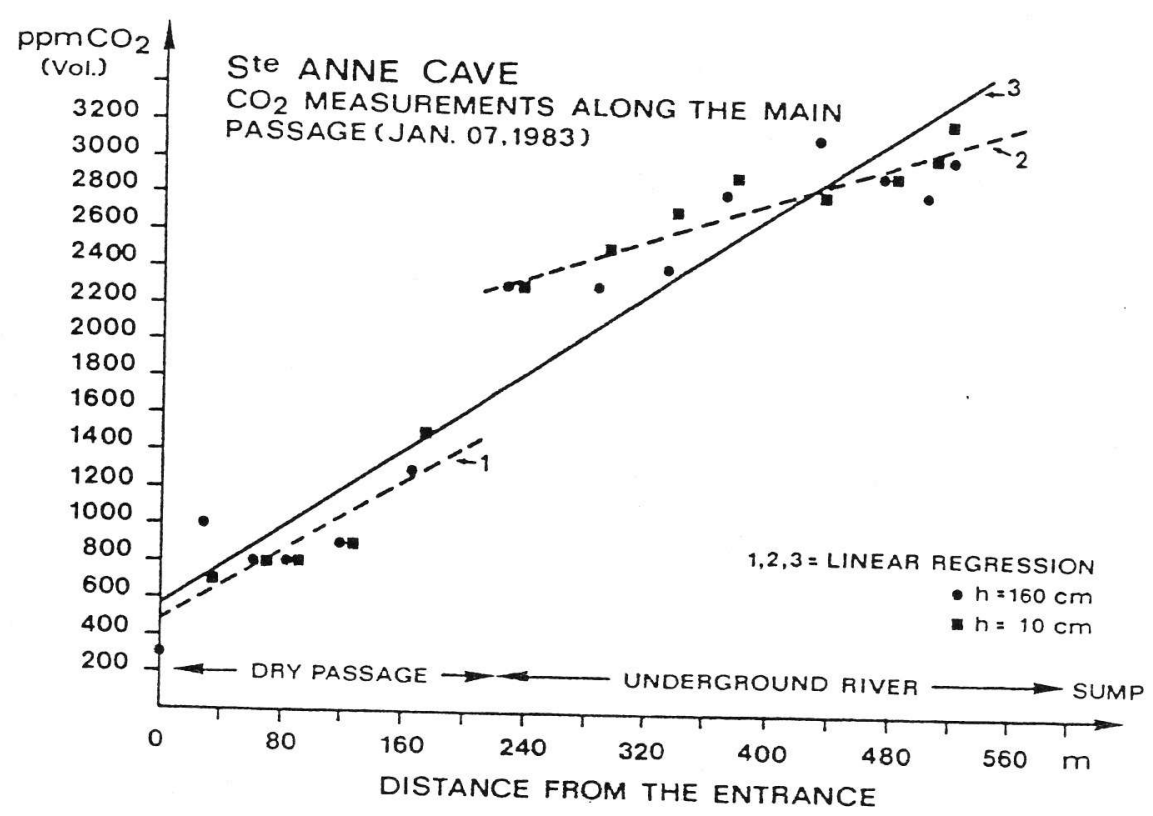

Figure 10. Horizontal evolution of $\mathrm{CO}_{2}$ content of air in Ste-Anne cave. Linear regressions: (1) $y=4 \cdot 7 \times+484 \cdot 7(r=0 \cdot 83)$;

(2) $y=2.6 x+1719.7(r=0.89) ;(3) y=5 \cdot 3 x+563.3(r=0.96)$ (after Gewelt and Ek, 1985)

We just want to show here some examples of the control of human breathing on $\mathrm{CO}_{2}$ measurements.

Contamination due to the operator

The following examples will prove the necessity of carrying out $\mathrm{CO}_{2}$ measurements with a gas absorber system, particularly in confined atmosphere, like fissures and very narrow galleries.

-In Ste-Anne cave (September 26, 1982), a measurement done in a fissure with the $\mathrm{CO}_{2}$ absorber gives $3800 \mathrm{ppm}$. In the same fissure, after breathing for five minutes at about $1 \mathrm{~m}$ from the measurement site, we measured $5000 \mathrm{ppm}$. This represents an increase of 32 per cent.

-In Brialmont cave (January 21, 1982) a measurement in the fissure F1 was done rapidly, without gas absorber and avoiding breathing. The result is $1000 \mathrm{ppm}$. The same measurement was carried out after six exhalations in the fissure and we found $1900 \mathrm{ppm}$ (i.e. increase of 90 per cent).

-In the Trou Joney (Comblain-au-Pont), five measurements were done with and without the $\mathrm{CO}_{2}$ absorber system. Three pairs of measures have been done in a corridor of about $1 \mathrm{~m}^{2}$ section: the $\mathrm{CO}_{2}$ average contents increases by 80 per cent passing from $1 \cdot 18,1 \cdot 66$, and $1.72 \mathrm{mg} \mathrm{CO}_{2} / 1$ to $2 \cdot 34,3 \cdot 12$, and $2.88 \mathrm{mg} / 1$ respectively. At the extremity of the cave, in the distal room, $\mathrm{CO}_{2}$ concentrations pass from 2.03 and $2.32 \mathrm{mg} / 1$ to 5.96 and $6.46 \mathrm{mg} / \mathrm{l}$. This represents an increase of 190 per cent (measurements date: December
7, 1969: Ek, unpublished).

Contamination due to the cavers and the tourists

- In Rochefort cave, in a big chamber, the initial $\mathrm{CO}_{2}$ concentration in the air is $2.30 \mathrm{mg} / \mathrm{l}$. The presence of three operators for five hours gives a measurement of $3.31 \mathrm{mg} / 1$ which represents an increase of 44 per cent (measurement date: September 30, 1969: Ek, unpublished).

-In Ste-Anne cave (May 28, 1982), a measure in the gallery gave $4000 \mathrm{ppm} ; 20$ minutes after the passage of 18 cavers (with two carbide lamps), a second measurement was carried out and $4800 \mathrm{ppm}$ was recorded (i.e. an
increase of 20 per cent).

- In Remouchamps cave, Mérenne-Schoumaker (1975) has observed, with one of us (Ek), that the presence of about 20 tourists causes an immediate increase of $0.25 \mathrm{mg} / \mathrm{l}$ in the narrow galleries. This represents a direct increase of the initial $\mathrm{CO}_{2}$ content of 6 per cent. During a whole day in the tourist season, the increase
is more important: about 30 per cent. 
We consider thus that the $\mathrm{CO}_{2}$ absorber system is a real necessity for measurements in confined places. In another way, the $\mathrm{CO}_{2}$ production by the cavers is difficult to avoid and we must perhaps deduct a $\mathrm{CO}_{2}$ background. The $\mathrm{CO}_{2}$ peaks are also partly correlated with a maximum of caving activity during the summer. Therefore noise reaches a maximum during this period. Another difficulty is that the $\mathrm{CO}_{2}$ concentration, increased by human $\mathrm{CO}_{2}$, does not rapidly decrease to its initial value (Ek et al., 1981).

\section{RESULTS AND DISCUSSION FOR CAVES IN OTHER COUNTRIES}

Carbon dioxide measurements become increasingly numerous under all climatic conditions. We shall here use the classification of Troll and Paffen (1964) who distinguish, beside the Cool-temperate Zones, two series of colder zones - the Polar and Subpolar Zones and the Cold-temperate Boreal Zone-and two series of warmer zones-the Warm-temperate Subtropical Zones and the Tropical Zone.

\section{The Cold Climatic Zones}

In the Subpolar Zone, some fifty unpublished analyses by Ek in Labrador (summer 1979), under oceanic subpolar conditions, displayed very low values in soil and in cracks and fissures in dolomite. No true caves were found but, even under a thick soil cover or in deep cracks or just above spring waters, the $\mathrm{CO}_{2}$ content was always below $600 \mathrm{ppm}$.

In the Cold-temperate Boreal Zone, some 36 measurements carried out in Swedish Lapland, under continental boreal conditions, displayed figures never exceeding $850 \mathrm{ppm}$ in fissures and $450 \mathrm{ppm}$ outside the fissures (Figure 11: Ek, unpublished); $200 \mathrm{ppm}$ were recorded twice close to an underground torrent surface: such a low value, well under the mean value of outside atmosphere, is not unusual in cold climates. The mean of all measurements in $385 \mathrm{ppm}( \pm \sigma=150)$.

Around Lake Mistassini, in the Canadian boreal forest, about 20 analyses (Ek, 1981) displayed values reaching a maximum of $1300 \mathrm{ppm}$ in a small cave. The mean values found were $1100 \mathrm{ppm}$ in the soil, $450 \mathrm{ppm}$ in the open air under forest cover $800 \mathrm{ppm}$ in caves and fissures. It should be noted that all measurements here referred to in cold climatic zones (Labrador, Lapland and Lake Mistassini) were carried out in July and August.

Although much too scarce, these analyses of the air of cold regions show its paucity in $\mathrm{CO}_{2}$ content. This conclusion is strengthened by the computations of Ford (1971), Woo and Marsh (1977), and Roberge (1979), all based on water analyses in limestone regions, showing that in Canada the cold regions are poor in $\mathrm{CO}_{2}$ and that the tundra and the alpine meadows are poorer than the boreal forest. Concordant conclusions are

$S$

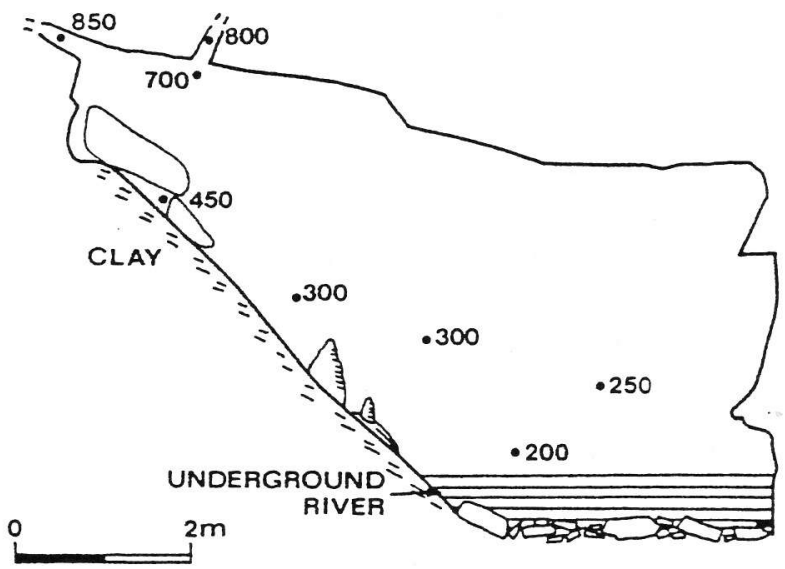

Figure 11. Lower Cave, at Bjorkliden (Swedish Lapland). Cross-section at $16 \mathrm{~m}$ from the cave entrance. $\mathrm{CO}_{2}$ content of the air in ppm (July 26, 1982) 

reached by Atkinson et al. (1983), by measurements in the air of Castleguard Cave, in the Canadian Rocky
Mountains, under the Columbia Icefields.

\section{The Cool-temperate Zones}

Under oceanic and suboceanic climates, measures are available in England, BelF̈ium, and France.

In England, Atkinson $(1975,1977)$ observes values rather similar to the ones of Belgium: in GB. Cave, 33 measurements display contents averaging $4100 \mathrm{ppm}$ in galleries and $8200 \mathrm{ppm}$ in the fissures with, in those places, a maximum of $16000 \mathrm{ppm}$.

This is concordant with the more than 600 analyses carried out in Belgium, where the range is $300-7000$ in the passageways and reaches a maximum of 9000 in fissures (this paper).

In France, where Renault (1982c) lists two to three thousand analyses, the $\mathrm{CO}_{2}$ content is much varying and reaches $70000 \mathrm{ppm}$. A CO 2 content of 40000 southern border of the Massif Central, the maximum $\mathrm{pCO}_{2}$ ranges are cited in relation with of 40000 to $50000 \mathrm{ppm}$ is frequently reported (Renault, 1982a). Lower $30000 \mathrm{ppm})$ are generally long horizontal horizontal too, but more ventilated, and caves, caves of $10 \mathrm{CO}_{2}$ content (1000 to $\left.10000 \mathrm{ppm}\right)$ are often $1000 \mathrm{ppm}$ ) are often two-e

(Renault, 1976).

correlated with meteorological parameters, morphology and the circulation of the air, and its evolution is example, Renault, 1968, 1976, 1979, 1982a, such as temperature, barometric pressure, and rainfall (see, for the causes of the high $\mathrm{CO}_{2}$ contents, one could, Renault and Brunet, 1981). Despite detailed developments on presence. As to the techniques and the question of air more critical discussion on possible influences of human 1962, 1963, 1964; Schoeller, 1950.

Under continental and subcontinenial climates, the measured values show considerable variations as well.

In Quebec, Ek (1981), having carried out some 200 analyses in all seasons, obtains a range of $\mathrm{CO}_{2}$ content going from 440 to $1100 \mathrm{ppm}$ in the galleries and chambers, whereas the fissures display maximum values in summer (up to $2800 \mathrm{ppm}$ ). A closed cave displays higher $\mathrm{pCO}_{2}$ (Figure 12).

These figures are in accordance with the measurements made in Poland, in the Silesian Upland (Ek et al., and a maximum of $1370 \mathrm{ppm}$ in the terminal fissure of the cave.
andime, 500 to $1100 \mathrm{ppm}$ in passageways

SW NE

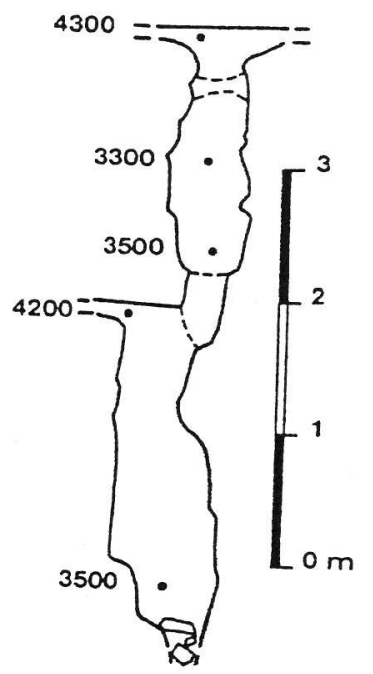
Figure 12. St-Leonard Cave, Montreal (Quebec, Canada). Cross-section nearby the far end of the cave. $\mathrm{CO}_{2}$ content of the air in ppm
(November 22, 1979) 
In the caves of Kentucky, 400 to 800 ppm were generally observed by Miotke (1974) in the galleries during the summer; in winter, he noted 400-600 ppm; the maximum value he observed was about $1300 \mathrm{ppm}$; all these observations were made in rather spacious caves.

In some caves of Ukraine, values ranging from 500 to 40000 are noted by Klimchuk et al. (1981); the highest figures are attributed to the abundance of organic matter in the concerned cave, and the possible (although not measured) occurrence of $\mathrm{CH}_{4}$, possibly immediately oxydized in $\mathrm{CO}_{2}$; the occurrence of gypsum is also noted.

Lewis (1981) has studied a cave under a cultivated area, and frequently invaded by organic matter. The author ascribes to the latter fact the high $\mathrm{CO}_{2}$ content -5000 to $25000 \mathrm{ppm}-$ of the cave.

Few measurements are known to us in the caves of the mountain climates of the cool-temperate zones. In the Swiss Alps, one $\mathrm{CO}_{2}$ measurement was done by Forel (1865) in a cave near Saint-Maurice. In Bödmerenalp Cave, above the Hölloch Cave, Bögli (1970) finds a very poor $\mathrm{CO}_{2}$ content (160 ppm), in relation to the high altitude of the cave $(1670 \mathrm{~m})$ and the strong wind outside. In the galleries of the Höloch Cave, $\mathrm{CO}_{2}$ contents are low-from 250 to $400 \mathrm{ppm}$-but, in confined places connected with the saturated zone, Bögli (1970) measures $1300 \mathrm{ppm}$, the highest observed value in this cave. Gomparable values were also found during the 1973-1974 winter (Bögli, 1975).

In the Polish Carpathians, Ek et al. (1969) have found in four caves, during the snow-melt, 200 to $1100 \mathrm{ppm}$ (40 titrations) and a maximum of $2000 \mathrm{ppm}$ in a fissure.

In the low and middle French Pyrenean Mountains, $\mathrm{pCO}_{2}$ exceptionally reaches $14000 \mathrm{ppm}$ (Renault and Brunet, 1981). Generally, however, the $\mathrm{CO}_{2}$ content of the air is lower in the mountain caves than in caves of lower altitude (Renault, 1968).

\section{The Warm-temperate Subtropical Zones and the Tropical Zone}

In Northern Italy, a cave of the Ligurian coast displays $\mathrm{pCO}_{2}$ values ranging from 400 to 800 ppm; the maximum $\mathrm{pCO}_{2}(1500 \mathrm{ppm})$ was observed in a fissure (24 measurements: Gewelt and Ek, 1983).

In the atmosphere of the caves of Bungonia (New South Wales, Australia), considerable amounts of $\mathrm{CO}_{2}$, biologically produced, are always present (James, 1977).

In the north of Madagascar, the seasonal evolution of the carbon dioxide of soil air was studied by Rossi (1974). The measured values range from 5000 to $32000 \mathrm{ppm}$, this maximum being observed in the humic horizon, at the beginning of the rain season. Measurements carried out above that humic horizon, at the base of the litter, display a lower $\mathrm{CO}_{2}$ content.

\section{CONCLUSION}

It seems clearly established now that the $\mathrm{CO}_{2}$ present in caves has generally a predominant organic origin. It is thus less abundant, for instance, under cold climates.

Phenomena such as the climatic variations, the seasonal rhythms, the greater abundance in the fissures connecting the caves with the soil, the varied gradients are indeed largely interconnected.

We believe that in some cases, high $\mathrm{CO}_{2}$ contents are partly resulting from human perturbations. As a consequence, the use of a $\mathrm{CO}_{2}$ absorber system is necessary, particularly in confined places. In caves frequently visited by cavers or tourists, the human influences on $\mathrm{CO}_{2}$ measurements are difficult to avoid, but this fact must be taken into account for the interpretation of the results.

Other acids can dissolve limestone in natural environments. But the paramount importance of $\mathrm{CO}_{2}$ is evident. Limestones, which are so largely biogenic, remain thus after their formation permanently involved in the biological cycles of our planet, of which they form an original and very characteristic component.

Atmosphere and organic reactions are not the only origins of the carbon dioxide; $\mathrm{CO}_{2}$ can be produced by inorganic reactions, originate from the depth of the Earth, etc. These origins and their relative importance, as well as $\mathrm{CO}_{2}$ variations during the Quaternary climatic changes are still a wide-open research field. Stable isotopes and ${ }^{14} \mathrm{C}$ analyses could certainly contribute to this topic. 


\section{ACKNOWLEDGEMENTS}

This work has been supported by Research Grants of the National Fund for Scientific Research (Belgium) Nicole Lousberg for her to Professor A. Pissart for his many valuable comments. They wish also to thank English adaptation of this paper.

\section{REFERENCES}

Adams, C. S. and Swinnerton, A. C. 1937. 'Solubility of limestone', Trans. Am. Geoph. Union, Pt. 2, 504-508.
Atkinson, T. C. 1975. 'Carbon dioxide in the atmosphere of the unsaturated zone: an important contol of

Atkinson, T. C. 1977. 'Carbon diss, Alabama, Abstract, 498 . limestones', $J$. of Hydrology, 35, 111-123.

Atkinson, T. C.

in

Canada', Arctic and Alpine Research, 15 (4), 487-502.
Bakalowicz, M. 1979. 'L'anhydride carbonique dans

'Clumbia Icefields, Alberta

Mägli, A. $1969 . \mathrm{CO}_{2} \cdot$ Gehalte der Luft in alpinen Karstböden und 1 . A.K., 41-48.
Bögli

Bögli, A. 1970. 'Le Hölloch et son karst', Stalactite, suppl. 4, 109 pp.
Bögli, A. 1975. 'Beobachtungen zum $\mathrm{CO}_{2}$-Gehalt der Luft im $\mathrm{H}^{2}$.lloch', Abh. V. Int. Kongr. Speläol., Stuttgart, 2, S28/1-9.

9, 68-71.

Bögli, A. 1976. $\mathrm{CO}_{2} \cdot$ 'Gehalte von Luft und Kalkgehol Spéléo, Interlaken, 1974. Stalactite, suppl. 153-163.

Delecour, F. 1965. 'Détermination des activités bol Wassern im unterirdischen Karst', Z. Geomorph. N. F., Suppl.-Bd., 26,

$\mathrm{du} \mathrm{CO}_{2}$ ', Note de Recherche $n^{\circ} 2$, Centre d'Ecopédologie forestière, Gembloux.
Delecour, F., Ek, C., and Weissen, F. 1968. 'An electardisation et essai de la technique du dosage $131-136$.

Delhez, F. 1972. 'La teneur en $\mathrm{CO}_{2}$ dans les biotion of $\mathrm{CO}_{2}$ in air', Nat. Speleol. Soc. Bull., 30,

Dever, L., Durand, R., Fontes, J.-C., and Vachier, P 1983. 'Ces arthropodes troglobies terrestres de la faune belge', L'Electron, 1 , 39

calcite dans un sol sur craie', Geochim. Cosmochim. Acta, 46, 1947-1956.
Dumont, J.-L., Bonvallot, J., Delhoume, J.-P., and Hiques des systèmes saisonniers de dissolution de la

calcaire', Cah. O.R.S.T.R.O.M. série J.-P., and Hiolle, P. 1983. 'Etude expérimentale de la mobilisation de

Ek, C., Delecour, F., and Weissen série Pédol. 20(1), 3-25.

Ek, C., Delecour, F., and Weissen, F. 1968. 'Teneur en C. de '.

Ek, C. 1969. 'Abondance du gaz carbonique dans des fissure de grottes', $V$. Int Kues grottes belges', Ann. Spéléol., 23, $243-257$.

the air in five Polish caves', Z., Kobylecki, A., Oleksynowa, K., and Oleksynowna, B. 1969. 'Some analyses of. Bd. 2, 14/1-14/3.

Ek, C. 1979. 'Variations saisonnières des teneu. N. F., 13, 267-286. 102, $71-75$.

Ek, C. 1981. 'Mesures du $\mathrm{CO}_{2}$ dans l'air des grottes:

672-673.
Ek, C., Caron, D., and Roberge, J. 1981. 'La forte teneur en de Montreal', Naturaliste can., 108, 57-63.

Ford, D. C.

Forel, M. 1865. 'Visite à la Grotte do Southern Rocky Mountains and Selkink Mountains', Can. J. Earth Sci., 8,

Galimov, E. M. 1966. 'Carbon isotopes of soil CO'. vaudoise Sc. nat. (Lausanne), 8, 247.

Gewelt, $\mathrm{M}$. and $\mathrm{Ek}, \mathrm{C}$. 1983. 'Le $\mathrm{CO}_{2}$ de l'air d'une grotte des Alpes ligures: la Caverna delle
Géograph. Liège, 19, 107-117.

Gewelt, M. and Ek, C. 1985. 'L'évolution saisonnièredes la Caverna delle Fate. Premières mesures', Bull. Soc. New Directions in Karst. Geo Books/Geo Abstracts Ltd, Norwich (in press).

Haas, H., Fisher, D W Thorstenom

25(2), 301-314.
Hilger, F. 1963. 'Activité respiratoire des sols équatoriaur,

Rech. Gembloux, 31, 154-182.
Jakucs, L. 1977. Morphogenetics of Karst Regions, équatoriaux. Application de la méthode respirométrique in situ', Bull. Inst. Agron. Stat.

James, J. M. 1977. 'Carbon dioxide in cave atms, A. Hilger (Bristol), 284 pp.

Klimchuk, A. B., Yablokova, N. I in cave atmosphere', Trans. Brit. Cave Res.

karst caves of Podolia and B. L., and Olshtynsky, S. P. 1981. The regularities in the for., 4, 417-429.

Koepf, H. 1952. 'Laufende Messung der Boden Internat. Congress of Speleology, U.S.A., 1, 21-23.

Lewis, W. C. 1981 'Carbonde Messung der Bodenatmung im Freiland', Landw. Forsch.A., 1, $21-23$.

Mérenne-Schoumat. 'Carbon dioxide in coldwater cave', Eighth Internat. Congress of Speleology. 184.

30(2), 273-285.

Miotke, F.-D. 1974. 'Carbon dioxide and the soil atmo grotte de Remouchamps', Ann. Spéléol.,

Nicod, J. 1975. 'Variation du $\mathrm{CO}_{2}$ dans les sols', Symposium on Karst denudation, Ljubljana Reihe A, 9, 1-49. 
Paterson, K. 1979. 'Field studies of limestone erosion processes, Oxfordshire Scarplands, England', Actes Symp. int. Erosion karstique, U.J.S., Aix-en-Provence, Marseille, Nîmes, mém. 1, A.F.K:, 87-95.

Renault, P. 1968. 'Sur la distinction de plusieurs régions karstiques en raison de la teneur en anhydride carbonique des atmosphères de grottes', C. R. Acad. Sci. Paris, 267 (D), 2288-2290.

Renault, P. 1976. 'Le gaz carbonique dans les grottes du Quercy', Bull. Comité Départ. Spéléo. Lot., 2, 94-104.

Renault, P. 1979. 'Mesures périodiques de la $\mathrm{pCO}_{2}$ dans des grottes françaises', Actes Symp. int. Ersion karstique, U.I.S., Aix-enProvence, Marseille, Nîmes, mém. 1, A.F.K., 17-33.

Renault, P. and Brunet, J. 1981. 'Les variations de la $\mathrm{pCO}_{2}$ atmospherique dans les grottes des Pyrénées centrales-grottes de Moulis et de Niaux (Ariège)', Colloque de Seyssins sur le karst, F.F.S., 5-18.

Renault, P. 1982a. 'Le $\mathrm{CO}_{2}$ dans l'atmosphère de quelques cavernes du Quercy (Département du Lot-France)', Spéléo-Dordogne, 74, 3-115.

Renault, P. 1982b. 'Rôle de la morphologie et du climat dans le transfert du $\mathrm{CO}_{2}$ au niveau de la surface aquifère, $3 e$ Colloque $\mathrm{Hydrologie}$ en Pays calcaire, Neuchatel-Besançon 1982, Ann. Sc. Univ. Besançon, Géologie, Mém. 1, 281 pp. (5 pp).

Renault, P. 1982c. ' $\mathrm{CO}_{2}$ atmosphérique karstique et spéléomorphologie. Intérêt pour les spéléologues', Rev. belge de Géographie, 106, $121-130$.

Roberge, J. 1979. Géomorphologie du Karst de la Haute Saumons, ile d'Anticosti, Québec, M.Sc. Thesis, Mc Master Univ., Hamilton, 217 pp.

Roques, H. 1956. 'Sur l'existence d'un gradient karstique des pressions partielles de l'acide carbonique', C. R. Acad. Sci. Paris, 242, 31003102.

Roques, H. 1959. 'Sur la répartition du $\mathrm{CO}_{2}$ dans les karsts', Ann. Spéléol., 14, 9-22.

Roques, H. 1962. 'Appareillages pour le dosage de $\mathrm{CO}_{2}$ dans les mélanges gazeux. (Note de laboratoire)', Ann. Spéléo., 17 (3), $455-462$.

Roques, H. 1963. 'Sur la répartition du $\mathrm{CO}_{2}$ dans les karsts (2e mémoire)', Ann. Spéléo., 18 (2), $142-184$.

Roques, H. 1964. 'Contribution à l'étude statique et cinétique des systèmes gaz carbonique-eau carbonate', Ann. Spéléo., 19(2), $255-484$.

Rossi, G. 1974. 'Sur une série de mesures de teneurs en $\mathrm{CO}_{2}$ de sols tropicaux', Bull. Ass. Géogr. Franç., 415-416, $141-144$.

Rossi, G. 1976. 'Karst et dissolution des calcaires en milieu tropical', Z. Geomorph. N. F., Suppl.-Bd., 26, 124-152.

Rossi, G. 1979. 'Quelques observations sur le $\mathrm{CO}_{2}$ dans les sols tropicaux et leurs conséquences possibles sur la dissolution des calcaires', Actes Symp. int. Erosion karstique, U.I.S., Aix-en-Provence, Marseille, Nimes, mém. 1, A.F.K., 35-39.

Russel, E. J. and Russel, E. E. 1950. Soils Conditions and Plant Growth, 8th ed., London, 688 pp.

Schoeller, H. 1950. 'Contribution à l'étude statique et cinétique des systèmes gaz carbonique-eau-carbonate', C.R. Acad. Sci., Paris, 230, $560-561$.

Troll, C. and Paffen, K. H. 1964. 'Karte der Jahreszeitenklimate der Erde', Erdkunde, Bd., 18(1), 5-28.

Woo, M. K. and Marsh, P. 1977. 'Effect of vegetation on limestone solution in a small High Arctic basin', Can. J. Earth Sci., 14, 571-581. 